\title{
Article
}

\section{Excavations at Knowth Volume 6: The Passage Tomb Archaeology of the Great Mound at Knowth}

\author{
Cummings, Vicki
}

Available at http://clok.uclan.ac.uk/26400/

Cummings, Vicki ORCID: 0000-0001-9460-1517 (2019) Excavations at Knowth Volume 6: The Passage Tomb Archaeology of the Great Mound at Knowth. Archaeological Journal, 176 (2). pp. 369-372. ISSN 0066-5983

It is advisable to refer to the publisher's version if you intend to cite from the work. http://dx.doi.org/10.1080/00665983.2019.1590956

For more information about UCLan's research in this area go to http://www.uclan.ac.uk/researchgroups/ and search for < name of research Group>.

For information about Research generally at UCLan please go to http://www.uclan.ac.uk/research/

All outputs in CLoK are protected by Intellectual Property Rights law, including Copyright law. Copyright, IPR and Moral Rights for the works on this site are retained by the individual authors and/or other copyright owners. Terms and conditions for use of this material are defined in the policies page.

\section{CLoK}

Central Lancashire online Knowledge www.clok.uclan.ac.uk

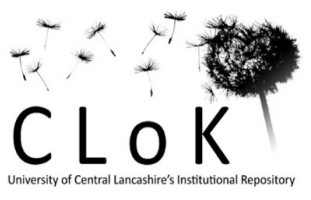




\section{REVIEW ARTICLE}

\section{Excavations at Knowth Volume 6: The Passage Tomb Archaeology of the Great Mound at Knowth}

VICKI CUMMINGS, Professor of Neolithic Archaeology, University of Central Lancashire

\section{Excavations at Knowth Volume 6: The Passage Tomb Archaeology of the Great Mound at}

Knowth, edited by George Eogan and Kerri Cleary, Dublin, Royal Irish Academy (Royal Irish Academy Monographs in Archaeology), 2017, lvii and 838 pp., Illus. 397. £45.00 (Hardback), ISBN: 9781908996763

The Brú na Bóinne complex in County Meath, Ireland, is one of the greatest Neolithic landscapes in northern Europe. Anyone who has ever had the chance to see these sites will know that these are truly monumental feats of engineering and it is only through experiencing these sites first hand that one is able to appreciate the size and scale of the monuments in this landscape. Rightly so, these sites have featured heavily in narratives of the Irish Neolithic where they are often described as the pinnacle of megalithic design and construction. These sites, however, cannot be considered 'typical'. While there are other, large passage tombs, and other complexes of sites such as Loughcrew and Carrowkeel, Brú na Bóinne stands apart in terms of the sheer scale of the megalithic endeavour. These monuments have also been subjected to extensive amounts of research and fieldwork over the years, much still ongoing. Indeed, despite this landscape having been the focus for research for decades, new discoveries are being made all the time, as we saw in the summer of 2018 when drought conditions revealed previously unknown sites through parch marks seen from above.

The volume being reviewed here reports on work conducted at Knowth, one of the three 'great mounds' - the three largest passage tombs in this complex comprising Knowth, Newgrange and Dowth. The great mound at Knowth consists of two separate chambers with long passages aligned roughly east-west and west-east respectively. The chambers and passages are covered by an enormous circular mound, which itself is surrounded by a series of smaller 'satellite' passage tombs. While a visitor to the site can be awed by the sheer scale of these sites on the ground, the reader of this volume can equally be overwhelmed by the scale of the excavations conducted here. The quantity of archaeology investigated at Knowth, both Neolithic and later, is demonstrated by the fact that this is the sixth volume in the series - covering 'just' the excavation of the large passage tomb. At over 800 pages in length this is a weighty tome, but 
beautifully presented with many colour images including 3D models and Ken Williams' stunning photos. Priced at $£ 45$ this offers exceptional value for money and is an absolute must-have for anyone interested in passage tombs in Europe or Irish archaeology.

The volume begins with an introduction to the site and the excavations conducted between 1962 and 2000. As already mentioned, this site is multi-phase and this volume reports only on the Neolithic components of the great mound. Moreover, another, separate, volume will follow shortly on the megalithic art within this monument so that is not discussed in any detail in this book. In the introduction Eogan's account of the discovery of the two chambers at Knowth makes for compelling reading early on and conjures up the excitement of the earliest work here.

The second chapter describes the excavation results of the Neolithic phases of the great mound. It is quite clear that this was a multi-phase endeavour, beginning with the construction of a large monument which itself may have been using stones taken from another monument. Little is known about this earliest phase, but the second burst of building involved the construction of both chambers with short passages. Occupation evidence was also found in this phase. It was the extension of the passages and thus the enlarging of the covering mound which created the monument visitors see today, and this phase also saw the addition of the kerb stones. The narrative of constructional events is clear and easy to read and really well illustrated throughout to help the reader understand the different components and phases of the site. For me the discussion on the makeup of the mound was of particular interest, since elsewhere myself and Colin Richards have explored the idea of 'wrapping' at passage tombs (Cummings and Richards 2017). There we suggested that passage tombs were, in part, about containment, whether that be the containment of the dead, or other, potent otherworldly beings. We suggested that one of the ways of achieving containment was through wrapping by which we meant the addition of multiple different substances in the encircling mound. The addition of different substances brought in from other parts of the landscape is clearly present at Knowth (see, for example, figure. 2.44, and discussed again later on p. 761) and there is no rational explanation for this, so the idea of wrapping appears apposite here too. Indeed, Richards has argued that wrapping was an important architectural device utilised to great effect throughout late Neolithic Britain and Ireland (Richards 2013). At the end of the chapter is an appendix which demonstrates that the two passages and chambers at the great mound are not aligned on sunrise or sunset at any of the key events in the calendar, which makes a striking contrast to Knowth's neighbour, Newgrange, where an alignment on midwinter sunrise can clearly be demonstrated. This means that the site is in-keeping with ideas of wrapping deployed 
elsewhere at similar sites, but the builders did not relate the site specifically to celestial alignments.

The next three chapters deal with the human remains from Knowth from three different perspectives. Chapter three details the osteological analysis of the human remains recovered from the great mound along with some of the satellite tombs. The largest assemblage is the 178 individuals recovered from the east chamber of the great mound, a large number of burials from any Neolithic context. The bulk of these were cremated, although there are a significant number of unburnt remains as well. The preponderance of cremation limits the amount of data which can be retrieved from their analysis: for example, cremation makes ageing and sexing more problematic (impossible in some instances) as well as the identification of disease or trauma. So the addition of new data from the skeletal remains here is a welcome addition to known material from passage tombs in Ireland. The authors draw on findings from two other sites in Ireland with inhumation deposits (Poulnabrone and Annagh) and find consistencies with the results from Knowth. They also note that there is plenty more scope for further study, and a new paper just published (Meehan and Hensey 2018) indicates this would indeed be timely and informative.

Next, chapter four considers the dating evidence from Knowth. The radiocarbon dates show early Neolithic pre-mound activity and occupation, along with possible burial activity. Again, the focus is on the east chamber where the authors demonstrate a main burial phase of 3200-2900 cal. BC, with some very tentative suggestions of pre-3200 BC activity discussed. There is also the possibility, indicated through Bayesian modelling, that the bulk of the burials took place within a tighter timeframe. This once again shows the usefulness of Bayesian analysis in producing more refined chronologies which can help us write more nuanced narratives on people and processes within their wider European context (see, for example, Whittle et al. 2011). Knowth, it appears, may have seen a short burst of burial activity instead of acting as an ossuary for many successive generations. This has been argued elsewhere (for some early Neolithic chambered tombs in southern Britain: Bayliss and Whittle 2007) and is overturning narratives that these were sites in use for extended periods. This leads us nicely onto chapter five written by Gabriel Cooney which considers the mortuary practices at Knowth in their wider context. Of particular note in this discussion is a challenge to the idea that cremation was the dominant mortuary practice in relation to passage tombs. Cooney argues that while cremation was clearly important it was part of a much more complex set of secondary mortuary practices. It appears that at the time of passage grave construction the vast majority of people were not buried. This is no surprise because it is a continuation of early Neolithic mortuary practice. However, those 
who ended up in passage tombs went through different, and sometimes quite complex, mortuary practices. Cremation of course did occur but alongside disarticulation, the selection of some skeletal elements as well as the cremation of green and dry bone. Deposition, then, was potentially at the end of a long sequence of events which dealt with the remains of the 'distinguished dead'.

Chapter six considers the artefactual assemblage from Knowth, including, in my opinion, one of the most spectacular and beautiful pieces of material culture from the Neolithic, the Knowth macehead. The chapter begins with a catalogue but expands to compare different types of object in their wider Irish and British context. The fragmentation of objects being deposited in the monument is striking and noted by the authors here. Several specialist chapters then follow starting with chapter seven which explores the origins of the stones used in the monument at Knowth. This is interesting because the Brú na Bóinne monuments are renown for utilising stones from a wide range of sources. The chapter considers not just the stones in the monument but also those cobbles and stones placed around the entrances. Indeed, this chapter provides supporting evidence for previous claims that people were willing to travel long distances to acquire special/distinctive stones from other parts of Ireland. The authors also provide a nice summary figure (Fig. 7.6) showing where the stones were likely to have been sourced.

Chapter eight considers the environmental evidence from the site in its wider landscape context. This is a large and comprehensive chapter and while the authors highlight that there is still much to be done, this work represents a significant step forward. It covers the identification of palaeochannels of the River Boyne, pollen core results, soil micromorphology, charcoal and wood analyses along with insect remains and the faunal assemblage. The emerging picture is that the monuments at Brú na Bóinne were constructed in open, pastoral grassland but that both woodland and cereal crops were close by. In the next chapter the conservation and restoration work conducted at Knowth is discussed. To have this documented is important because the approach to conservation and the subsequent presentation of these monuments to the public has changed considerably over the last few decades. Moreover, Newgrange remains a controversial restoration, particularly in relation to the placing of the white quartz stones. This chapter clarifies why certain decisions were made in relation to the preservation and presentation of this site.

The final chapter is a wider discussion chapter. For me, this is where the only misstep in the volume appears. It is always difficult to write a discussion at the end of a book, even more so perhaps at the end of so much detailed work. I felt the rather superficial summary of what are 
quite complex debates relating to the origins and spread of megalithic architecture was not very satisfactory and relied too heavily on older synthetic treatments of this topic instead of the most up-to-date considerations. This included a lack of critical thinking around typology, something which is now significantly hampering megalithic studies. For me, I would have cut this and just provided a summary of the biography of site as the authors do later in the chapter. This provides a useful outline of what has been detailed earlier on and rightly focuses on comparisons with other Irish sites, especially those that have been excavated such as the Mound of the Hostages.

Overall, though, this volume makes an excellent addition to the recent and impressive range of literature on the Irish Neolithic, including the publication of excavations at Poulnabrone (Lynch 2014) and various Irish house sites (Smyth 2014) alongside more interpretive work such as Hensey's book on passage tombs (Hensey 2015), the use of caves (Dowd 2015) and specific targeted research projects (e.g. Whitehouse et al. 2014). It certainly is an exciting time to be researching the Irish Neolithic and this book both presents the details of an extended excavation project while also placing those findings in a much wider context throughout, incorporating research undertaken in Ireland, Britain and Northern Europe more broadly. The volume also highlights future directions for research which is an important statement for what path further researches could take. It is a fitting testament to the size and scale of both the original Neolithic construction but also an astounding archaeological excavation lasting many years. I am looking forward to seeing the next volume in this series which considers the megalithic art at the site.

\section{BIBLIOGRAPHY}

Bayliss, A. and Whittle, A. 2007. Histories of the dead: building chronologies for five southern British long barrows. Cambridge Archaeological Journal 17:1.

Cummings V. and C. Richards. 2017. Passage graves as material technologies of wrapping. In P. Bickle, V. Cummings, D. Hofmann and J. Pollard (eds.), The Neolithic of Europe, 235-48. Oxford: Oxbow.

Dowd, M. 2015. The archaeology of caves in Ireland. Oxford: Oxbow.

Hensey, R. 2015. First light: the origins of Newgrange. Oxford: Oxbow.

Lynch, A. 2014. Poulnabrone: an early Neolithic portal tomb in Ireland. Dublin: Wordwell.

Meehan, P. and Hensey, R. 2018. Carrowkeel to Cambridge: resolving the origins of a Neolithic bone assemblage. Proceedings of the Royal Irish Academy 118c, 1-36.

Richards, C. 2013. Building the great stone circles of the north. Oxford: Windgather.

Smyth, J. 2014. Settlement in the Irish Neolithic. Oxford: Oxbow. 
Whitehouse, N., Schulting, R., McClatchie, M., Barratt, P. McLaughlin, T. Bogaard, A., Colledge, S., Marchant, R. Gaffrey, J. and Bunting, M. 2014. Neolithic agriculture on the European western frontier: the boom and bust of early farming in Ireland. Journal of Archaeological Science 51, 181-205.

Whittle, A., Healy, F. and Bayliss, A. 2011. Gathering time: dating the early Neolithic enclosures of southern Britain and Ireland. Oxford: Oxbow. 